\title{
Viral Hepatitis
}

National Cancer Institute

\section{Source}

National Cancer Institute. Viral Hepatitis. NCI Thesaurus. Code C35124.

An acute or chronic inflammation of the liver parenchyma caused by viruses.

Representative examples include hepatitis A, B, and C, cytomegalovirus hepatitis, and herpes simplex hepatitis. 